\title{
Hematological analysis and relative condition factor in naturally parasitized Nile tilapia
}

\author{
Lilian Dordete Steckert ${ }^{1}$, William Eduardo Furtado ${ }^{1}$, Gabriela Tomas Jerônimo ${ }^{1,2}$ \\ Karen Roberta Tancredo ${ }^{1}$, Gabriela Sayuri de Oliveira Hashimoto ${ }^{1}$ \\ Scheila Anelise Pereira ${ }^{1}$ \& Maurício Laterça Martins ${ }^{1}$ \\ ${ }^{1}$ AQUOS-Aquatic Animal Health Laboratory, Aquaculture Department \\ ${ }^{2}$ Federal University of Santa Catarina, Florianópolis, SC, Brazil \\ Corresponding author: Maurício Laterça Martins (mauricio.martins@ufsc.br)
}

\begin{abstract}
This study aimed to evaluate the hematological profile and relative condition factor of naturally parasitized Nile tilapia from 12 fish farms in southern Brazil. A total of 240 fish were collected from four regions of the state of Santa Catarina. They were anesthetized, and the blood was collected by puncturing the caudal vein. Subsequently, the fish were necropsied for parasitological analysis. The results were compared with the Kruskal-Wallis test, and the correlations were verified with the Spearman test $(P<0.05)$. The parasitological analysis revealed high infestations by Ichthyophthirius multifiliis on the fish gills of the south and west regions. The presence of Trichodina magna and Trichodina compacta was observed in low intensity on the body surface of fish from all facilities. Trichodina spp. was found in high intensity parasitizing the fish gills of northern, Itajaí valley and western regions, nonetheless, in those regions, the presence of Monogenea, Cichlidogyrus sclerosus, and Cichlidogyrus halli, on fish gills was observed. The hematological profile presented altered parameters, featuring monocytosis and thrombocytopenia, possibly associated with high parasitic intensities. The observed correlations suggest that neutrophils and monocytes are directly involved in an organic defense against parasites. Monocytes are mainly targeted in the defense against I. multifiliis.
\end{abstract}

Keywords: Oreochromis niloticus; Monogenea; Trichodina sp.; Ichthyophthirius multifiliis; monocytosis; thrombocytopenia

\section{INTRODUCTION}

Aquaculture currently accounts for half of all fish for human consumption in the world, reaching a record in 2014 , with per capita consumption of $20 \mathrm{~kg} / \mathrm{inha-}$ bitant/year (FAO, 2016). The preference for fish comes from several factors such as nutritional quality (rich in proteins and polyunsaturated fatty acids), sensory (pleasant and mild flavor), economic and convenience, presenting the potential for the market (MPA, 2015). In this context, Nile tilapia (Oreochromis niloticus) has characteristics favorable for culture and consumption (Khaw et al., 2012) and is widely marketed worldwide (Fitzsimmons et al., 2011). Nevertheless, it is the second most widely cultivated fish species in the world and the first in Brazil (Vicente et al., 2014).

With the intensification of culture system, a favorable environment for epizootic outbreaks is created, due to several factors that contribute to the onset of diseases (Tavares-Dias et al., 2009). Parasitic diseases are a limiting factor in fish production. Also, lesions caused by parasites serve as gateways for secondary infections (Takemoto et al., 2013; Valladão et al., 2014). Some studies suggest that parasites are also vectors of other pathogens, which can lead to acute mortality of fish (Xu et al., 2012; Pilloux et al., 2015). Ectoparasites are common in tilapia culture and have been reported by several authors (Ghiraldelli et al., 2006a; Jerônimo et al., 2011; Tavares-Dias et al., 2013; Nunes et al., 2016) and according to Moraes \& Martins (2004) are directly related to water quality and animal management.

Hematological analysis is a diagnostic tool that has been used in fish studies and shows normal and pathological equilibrium conditions (Azevedo et al., 2006). Blood parameters can be used as indicators to 
monitor the degree of fish health, effectively identifying responses to breeding challenges, such as the stress that the environment and pathogens cause to fish (Tavares-Dias et al., 2009; Ranzani-Paiva et al., 2013). Tavares-Dias et al. (2002) evaluating Nile tilapia from a fishery located in southeastern Brazil have observed that the parasitism by Ichthyophthirius multifiliis Fouquet, 1876 (Protozoa: Ciliophora) and Saprolegnia sp. caused anemia and an increase in the percentage of neutrophils and monocytes in fish. On the other hand, Ranzani-Paiva et al. (2005) and Ghiraldelli et al. (2006b) in parasitological studies with Nile tilapia originating respectively from cultures and dam, did not observe significant changes in hematological variables, a fact attributed to low parasite intensity. The authors concluded that the fish were in good health.

Another commonly used parameter to determine fish welfare is the relative condition factor $(\mathrm{Kn})$, measured by the relationship between the observed weight and the expected weight for a given length (Guidelli et al., 2009). It is expected that, under normal conditions, $\mathrm{Kn}$ is equal to 1 , but it is known that it can be influenced by numerous factors such as nutrition, contamination and parasites (Yamada et al., 2008). Analyzing the relative condition factor (Kn), RanzaniPaiva et al. (2000) and Tavares-Dias et al. (2002) have reported that the parasites did not significantly affect the health condition of the hosts. In contrast, Singhal et al. (1990) found that high infestation by Argulus indicus Weber, 1892 (Crustacea: Branchyura) and infection by Saprolegnia sp. significantly suppressed the growth of Cyprinus carpio. Tavares-Dias et al. (2000) reported that high parasite infection reduced welfare in O. niloticus, Leporinus macrocephalus and Piaractus mesopotamicus, which may retard fish growth and cause damage to the producer in different culture systems.

Although Nile tilapia is one of the most cultured and studied fish in the world, there are few parasitological studies associated with hematological characteristics and relative condition factor in this species. Thus, this study aimed to evaluate the health status through the hematological profile and the relative condition factor in Nile tilapia naturally parasitized in fish farms from southern Brazil.

\section{MATERIALS AND METHODS}

\section{Ethics statement}

The procedures adopted for this study were approved by the Committee on Ethics in the Use of Animals of the Federal University of Santa Catarina-CEUA $\mathrm{N}^{\mathrm{o} P P} 00928$.

\section{Study area}

Adult tilapia from 12 fish farms were collected, covering four regions of the State of Santa Catarina: north, south, Itajaí valley and west, with three fish farms per region. In each, 20 specimens were studied, totaling 240 fish.

During the year 2015, punctual collections were carried out in each of the 12 fish farms, located in the cities of Braço do Norte (28 $\left.16^{\prime} 30^{\prime \prime} \mathrm{S}, 49^{\circ} 09^{\prime} 57^{\prime \prime} \mathrm{W}\right)$ in the south of the state, Joinville (26 $18^{\prime} 14^{\prime \prime} \mathrm{S}, 48^{\circ} 50^{\prime}$ $\left.45^{\prime} \mathrm{W}\right)$ in the northern region, Gaspar (26.55'51'S, $48^{\circ} 57^{\prime} 32^{\prime \prime} \mathrm{W}$ ) in the Itajaí Valley, and three other fish farms west of Santa Catarina, in the cities of Caxambú

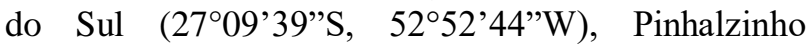
$\left(26^{\circ} 0^{\prime} 52^{\prime \prime} \mathrm{S}, \quad 52^{\circ} 59^{\prime} 31^{\prime \prime} \mathrm{W}\right)$ and Barra Bonita (26³9'14’S, 5326'24'W).

\section{Physical and chemical parameters of water}

During the sampling, the following water quality parameters were evaluated: transparency with Secchi disk, temperature, $\mathrm{pH}$ and dissolved oxygen with the aid of multiparameter (model HI 9828 - Hanna instruments), and ammonia with commercial Hanna ${ }^{\circledR}$ kit.

\section{Hematological analysis}

After fish capture with the aid of net, they were anesthetized with Eugenol Vetec ${ }^{\circledR}\left(75 \mathrm{mg} \mathrm{L}^{-1}\right)$ during one minute of exposition and the blood $(1 \mathrm{~mL})$ was collected by puncturing the caudal vessel, using a syringe with a $20 \times 0.55 \mathrm{~mm}$ ( $24 \mathrm{G}$ x 3/4") needle containing a drop of $10 \%$ EDTA. Blood smears were performed in duplicates, later stained with MayGrunwald/Giemsa/Wright, for total thrombocyte and leukocyte counts and differential leukocyte count. The counts of these cells were calculated by the indirect method, from the blood extensions (Ishikawa et al., 2008). An aliquot of the blood was used to determine the percentage of hematocrit (Ranzani-Paiva et al., 2013). The total erythrocyte count was performed in a Neubauer chamber, after dilution (1:200) in Dacie solution (Blaxhall \& Daisley, 1973).

\section{Parasitological analysis}

After blood sampling, the animals were euthanized by a rapid cerebral concussion, followed by a detailed macroscopic examination and biometry. The body surface mucus was scraped to make two slides each in duplicates that were later stained with silver nitrate and Giemsa to identify the protozoans. The remainder of the mucus was conditioned in flasks and fixed in 5\% formalin for further parasite counting. The eyes, gills and gastrointestinal tract were collected separately and fixed, according to Jerônimo et al. (2011). 
For protozoan quantification, the body surface and gill contents were homogenized and subsequently three $1 \mathrm{~mL}$ aliquots were taken for counting in the Sedgewick-Rafter chamber to estimate the volume of the fixed, as proposed by Martins et al. (2011). Monogeneans were quantified under a stereomicroscope in a labeled Petri dish and later mounted on slides with Hoyer's medium for identification.

Prevalence rate, mean intensity and mean parasite abundance were calculated according to Bush et al. (1997) for each parasite species. The identification of Trichodina sp. was performed according to Ghiraldelli et al. (2006c) and Martins \& Ghiraldelli (2008), and Monogenea according to Paperna \& Thurston (1969) and Pariselle \& Euzet (1995).

\section{Relative condition factor $(\mathrm{Kn})$}

Kn values were calculated according to the method described by Le Cren (1951). Thus, with the logarithms of the total length (Lt) and total individual weight $(\mathrm{Wt})$ values, the curve of the $\mathrm{Wt} / \mathrm{Lt}$ relationship was adjusted, and the values of the regression coefficients a and $b$ were estimated. The values of these coefficients were used to estimate the theoretically expected values of body weight $(\mathrm{We})$, using the equation $\mathrm{We}=\mathrm{a} \mathrm{Lt}^{\mathrm{b}}$. Then Kn was calculated, corresponding to the ratio between the observed weight and the theoretically expected weight for a given length $(\mathrm{Kn}=\mathrm{Wt} / \mathrm{We})$.

\section{Statistical analysis}

Statistical analyses were performed using Statistica $10.0^{\circledR}$ software. Since normality and homoscedasticity were not reached, the non-parametric Kruskal-Wallis test was used to compare the means. The possible correlations were verified with Spearman's correlation coefficient. The level of significance was $P \leq 0.05$.

\section{RESULTS}

The fish farms in this study were generally characterized by monocultures of tilapia, polyculture and catch and fee fishing systems (Table 1), and no mortalities were found.

The water quality values, measured only on the collection day, showed variations among the fish farms (Table 2). The mean weight of the animals ranged from 250.2 to $868.7 \mathrm{~g}$, while the mean maximum and minimum total lengths were 22.2 and $35.6 \mathrm{~cm}$, respectively.

The condition factor presented an average of one $(\mathrm{Kn}=1)$ in all fish farms in the present study, except for one in which the mean was 0.99 (Table 3).
The parasitological analysis revealed the presence of Trichodina magna Van as \& Basson, 1989 and Trichodina compacta Van as \& Basson, 1989 on the fish body surface of all fish farms, with a maximum prevalence of $95 \%$ and a minimum of $35 \%$, with a relatively low average intensity. Already the parasitism by Trichodina sp. Ehrenberg, 1830 on the gills, was reported in fish from all fish farms in the north, Itajaí valley and west, with prevalences of 40 to $100 \%$ and the high mean intensity of infestation (Table 4).

Ichthyophthirius multifiliis was observed in tilapia gills of all fish farms in the south and west regions, and only one of the northern regions of the state. The prevalence of I. multifiliis ranged from 5 to $100 \%$, and the mean intensity followed the variation, being more intense in fish farms with higher prevalences (Table 5).

Only two species of Monogenea were observed on the gills, Ciclidogyrus sclerosus Paperna \& Thurston, 1969 and Ciclidogyrus halli Price \& Kirk, 1967, well as Trichodina sp. were present in all fish farms in the north, valley and west region, and absent in fish farms in the south. The lowest prevalence observed was $15 \%$, where the lowest values for intensity and average infection abundance were also observed (Table 6). Prevalence of $100 \%$ was observed in fishery 3 of the Itajaí valley. However, the highest mean infestation intensity by Ciclidogyrus sp. was in the northern fish farm with $100.42 \pm 65.32$ parasites per fish.

The hematological parameters (Table 7) revealed variations in the red blood cells that presented minimum and maximum values of $1.4 \times 10^{6}$ and $2.4 \times 10^{6}$ $\mu \mathrm{L}^{-1}$, respectively, as well as the hematocrit, which ranged from 25.1 to $36.5 \%$, remaining within the reference values for the species (Azevedo et al., 2006; Ghiraldelli et al., 2006b).

Thrombocytes presented low values in all fish farms, characterizing thrombocytopenia. The total white blood cells count showed variations among the fish farms, with the most abundant leucocytes being lymphocytes, followed by monocytes and neutrophils. The monocytes presented marked values in all fish farms, which were consistent with a monocytosis. However, the lymphocytes and neutrophils, despite a wide variation, were within the reference values for the species (Azevedo et al., 2006; Ghiraldelli et al., 2006b).

When all the parasites were compared with each hemogram parameter, no correlation was observed between the hematological variables and the parasitism. However, monocytes were positively correlated with protozoan I. multifiliis $(\rho=0.19)$ and neutrophils showed positive correlations with I. multifiliis $(\rho=$ $0.25)$, Trichodina sp. on the gills $(\rho=0.18)$ and Monogenea $(\rho=0.15)$. The relative condition factor $(\mathrm{Kn})$ 
Table 1. Management characteristics in the different regions and fish farms in the state of Santa Catarina. *One year ago, was consortium with pigs. **In the winter the animals were not receiving feed, which coincided with the date of collection.

\begin{tabular}{|c|c|c|c|}
\hline \multicolumn{4}{|c|}{ South } \\
\hline Characteristics & Fish farming 1 & Fish farming 2 & Fish farming 3 \\
\hline System & Fish-pay & Monoculture* & Monoculture \\
\hline Density (fish m³) & 2 & - & $4-5$ \\
\hline Feeding & 2 times daily** & 3 times daily** & 5 times daily** \\
\hline Complementary Aeration & No & Yes & Yes \\
\hline Water Quality Monitoring & No & Monthly & No \\
\hline Prophylaxis & No & No & No \\
\hline Treatment of tanks & Disinfection between crops & Disinfection between crops & No \\
\hline \multicolumn{4}{|c|}{ North } \\
\hline Characteristics & Fish farming 1 & Fish farming 2 & Fish farming 3 \\
\hline System & Polyculture & Polyculture & Tank tank \\
\hline Density (fish m-3) & 4 & 2 & - \\
\hline Feeding & 2 times daily & 2 times daily & 1 time daily \\
\hline Complementary Aeration & Yes & Yes & Yes \\
\hline Water Quality Monitoring & Monthly & 1 time per week & No \\
\hline Prophylaxis & Salt & Salt & Salt \\
\hline Treatment of tanks & Fertilization & $\begin{array}{l}\text { Disinfection and fertilization } \\
\text { (uses manure) }\end{array}$ & No \\
\hline \multicolumn{4}{|c|}{ Itajaí Valley } \\
\hline Characteristics & Fish farming 1 & Fish farming 2 & Fish farming 3 \\
\hline System & Polyculture & Fish-pay & Polyculture \\
\hline Density (fish m ${ }^{-3}$ ) & 3 & $8-10$ & 5 \\
\hline Feeding & 3 times daily & 1 time daily & 5 times daily \\
\hline Complementary aeration & 2 times daily & 2 times daily & 2 times daily \\
\hline Water Quality Monitoring & 2 times per week & Não & Monthly \\
\hline Prophylaxis & Salt & Salt & Salt \\
\hline Treatment of tanks & $\begin{array}{c}\text { Disinfection and fertilization } \\
\text { between crops }\end{array}$ & Disinfection between crops & $\begin{array}{c}\text { Disinfection between crops and } \\
\text { fertilization sometimes }\end{array}$ \\
\hline \multicolumn{4}{|c|}{ West } \\
\hline Characteristics & Fish farming 1 & Fish farming 2 & Fish farming 3 \\
\hline System & Polyculture & Fish-pay & Polyculture \\
\hline Density (fish $\mathrm{m}^{-3}$ ) & 3.6 & 4 & 2.5 \\
\hline Feeding & - & 2 times daily & 8 times daily - automatic \\
\hline Complementary aeration & Yes & No & Yes \\
\hline Water Quality Monitoring & Monthly & No & Monthly \\
\hline Prophylaxis & No & Salt e and syrup with pine & No \\
\hline Treatment of tanks & $\begin{array}{l}\text { Drying, disinfection, and } \\
\text { fertilization between crops }\end{array}$ & $\begin{array}{l}\text { Drying, disinfection, and } \\
\text { fertilization between crops }\end{array}$ & $\begin{array}{l}\text { Drying, disinfection, and } \\
\text { fertilization between crops }\end{array}$ \\
\hline
\end{tabular}

when related to hematological indices and parasitism presented only negative correlation $(\rho=-15)$ with Trichodina sp. in the mucus.

\section{DISCUSSION}

Nile tilapia is a rustic fish capable of supporting lowquality water environments (Zaniboni-Filho, 2004). However, dissolved oxygen was relatively low in fish farms 1 and 2 in the south region and fish farming 2 in the west region. Likewise, the water temperature in most fish farms was below the ideal limit for their cultivation (Kubitza, 2000). In general, changes in water quality, high stocking density, inadequate management or unbalanced nutrition are factors capable of producing stress in the fish, predisposing them to various infestations and parasitic infections (Zanolo \& Yamamura, 2006).

The parasites reported in this study are common to tilapia culture, especially Monogenea and Trichodina sp. (Azevedo et al., 2006; Ghiraldelli et al., 2006a; Jerônimo et al., 2011; Zago et al., 2014; Nunes et al., 2016) and the protozoans have been shown to be the most prevalent group in Santa Catarina. Ranzani-Paiva et al. (2005), in a study with Nile tilapia from a reservoir in São Paulo, observed among other parasites, Trichodina 
Table 2. Physical and chemical parameters of water quality in the nurseries of the different fish farms studied. P: fish farming, DO: dissolved oxygen.

\begin{tabular}{|c|c|c|c|c|c|c|}
\hline \multirow{2}{*}{ Parameters } & \multicolumn{3}{|c|}{ South } & \multicolumn{3}{|c|}{ North } \\
\hline & P1 & $\mathrm{P} 2$ & P3 & P1 & $\mathrm{P} 2$ & P3 \\
\hline $\mathrm{DO}\left(\mathrm{mg} \mathrm{L}^{-1}\right)$ & 1.8 & 1.4 & 8.3 & 7.3 & 6.6 & 6.1 \\
\hline Transparency $(\mathrm{cm})$ & 21 & 20 & 19 & 11 & 13 & 41 \\
\hline $\mathrm{pH}$ & 6.1 & 7.0 & 7.0 & 6.6 & 6.8 & 7.0 \\
\hline Ammonia $\left(\mathrm{mg} \mathrm{L}^{-1}\right)$ & 1 & 0.5 & 0.2 & 0.1 & 0 & 0.1 \\
\hline Temperature $\left({ }^{\circ} \mathrm{C}\right)$ & 20.7 & 23.6 & 22.0 & 22.8 & 23.7 & 20.9 \\
\hline \multirow{2}{*}{ Parameters } & \multicolumn{3}{|c|}{ Itajaí Valley } & \multicolumn{3}{|c|}{ West } \\
\hline & P1 & $\mathrm{P} 2$ & P3 & P1 & $\mathrm{P} 2$ & P3 \\
\hline $\mathrm{DO}\left(\mathrm{mg} \mathrm{L}^{-1}\right)$ & 2.2 & 7.8 & 3.3 & 7.6 & 0.6 & 3.1 \\
\hline Transparency $(\mathrm{cm})$ & 14 & 6 & 20 & 21 & 19 & 20 \\
\hline $\mathrm{pH}$ & 6.4 & 7.0 & 6.0 & 6.7 & 5.9 & 5.8 \\
\hline Ammonia $\left(\mathrm{mg} \mathrm{L}^{-1}\right)$ & 1.5 & 0.1 & 1.0 & 1.6 & 0.2 & 0.6 \\
\hline Temperature $\left({ }^{\circ} \mathrm{C}\right)$ & 28.7 & 22.4 & 22.9 & 29.2 & 25.3 & 30.9 \\
\hline
\end{tabular}

Table 3. Biometric indices (mean \pm standard deviation) and relative condition factor $(\mathrm{Kn})$ of Nile tilapia. Different letters indicate a significant difference in the columns by the Kruskal-Wallis test $(P<0.05)$. P: fish farming.

\begin{tabular}{llcl}
\hline Fish farming & Weight $(\mathrm{g})$ & Length $(\mathrm{cm})$ & Kn \\
\hline P1 south & $362.3 \pm 124.3^{\mathrm{abc}}$ & $25.4 \pm 3.1$ & $1.0^{\mathrm{a}}$ \\
P2 south & $347.0 \pm 76.1^{\mathrm{abc}}$ & $24.2 \pm 1.6$ & $1.0^{\mathrm{b}}$ \\
P3 south & $250.2 \pm 52.0^{\mathrm{a}}$ & $23.3 \pm 1.6$ & $0.9^{\mathrm{c}}$ \\
\hline P1 north & $407.5 \pm 86.9^{\mathrm{bcd}}$ & $26.4 \pm 1.8$ & $1.0^{\mathrm{a}}$ \\
P2 north & $488.7 \pm 170.7^{\mathrm{cd}}$ & $28.3 \pm 3.3$ & $1.0^{\mathrm{a}}$ \\
P3 north & $422.8 \pm 166.3^{\mathrm{abcd}}$ & $28.4 \pm 3.7$ & $1.0^{\mathrm{a}}$ \\
\hline P1 valley & $261.5 \pm 50.6^{\mathrm{ab}}$ & $22.2 \pm 1.6$ & $1.0^{\mathrm{ab}}$ \\
P2 valley & $868.7 \pm 123.7^{\mathrm{e}}$ & $35.6 \pm 1.5$ & $1.0^{\mathrm{a}}$ \\
P3 valley & $372.9 \pm 71.9^{\mathrm{abc}}$ & $26.7 \pm 1.6$ & $1.0^{\mathrm{ab}}$ \\
\hline P1 west & $815.3 \pm 113.8^{\mathrm{e}}$ & $33.6 \pm 1.8$ & $1.0^{\mathrm{a}}$ \\
P2 west & $588.1 \pm 116.6^{\mathrm{de}}$ & $31.2 \pm 2.7$ & $1.0^{\mathrm{ab}}$ \\
P3 west & $511.0 \pm 7.7^{\text {cde }}$ & $29.4 \pm 1.5$ & $1.0^{\mathrm{ab}}$ \\
\hline
\end{tabular}

sp., Ichthyophthirius multifiliis and Monogenea on gills and Trichodina sp. on the fish skin, corroborating the parasitic fauna found in the present study. On the other hand, previous studies did not report the presence of $I$. multifiliis in fish from Santa Catarina while other ectoparasites such as Piscinoodinium pillulare (Schäperclaus 1954) Lom 1981 were found to be recurrent (Azevedo et al., 2006; Ghiraldelli et al., 2006a; Jerônimo et al., 2011; Nunes et al., 2016). The above suggests a possible variation of the parasitological fauna of Oreochromis niloticus among the fish farms and along with culture cycles in the same region.

The highest values of prevalence and the average intensity of Trichodina magna and Trichodina compacta on the body surface of fish from fish farms 3 in the southern region may be associated with the fact that drying and treatment of tanks between harvests were not performed. These management practices contribute to an environment conducive to the proliferation of these protozoa, since they are indicators of water quality, and are directly related to the concentration of organic matter in the environment (Jerônimo et al., 2011). In addition to poor water quality, its proliferation is also associated with the total number of bacteria and the ecological aspects of the host (Martins et al., 2015). Similar fact occurs in fish farming 2 of the northern region, which is the only one of the fish farms in this study that uses manure for fertilization of the tanks, contributing to a higher average intensity of Trichodina sp. in the gills of the fish at that site.

Ichthyophthirius multifiliis was the parasite that affected the fish of the west region with higher intensity. It is known to be a widespread infestation in times of lower temperatures in the southern and south- 
Table 4. Parasitological indices of Trichodina sp. in Nile tilapia. Different letters indicate a significant difference in the lines by the Kruskal-Wallis test $(P<0.05)$. P\%: prevalence, MI: mean intensity and MA: mean abundance (mean \pm standard deviation), SII: site of infestation/infection, G: gills, M: mucus of body surface, P: fish farming.

\begin{tabular}{lcrcc}
\hline Fish farming & SII & P $(\%)$ & MI & MA \\
\hline P1 south & G & 0 & $0^{\mathrm{a}}$ & 0 \\
& M & 65 & $12.3 \pm 15.2^{\mathrm{abc}}$ & $8.0 \pm 13.5$ \\
\hline P2 south & G & 0 & $0^{\mathrm{a}}$ & 0 \\
& $\mathrm{M}$ & 70 & $8.1 \pm 6.9^{\mathrm{abc}}$ & $5.7 \pm 6.8$ \\
\hline P3 south & $\mathrm{G}$ & 0 & $0^{\mathrm{a}}$ & 0 \\
& $\mathrm{M}$ & 95 & $97.2 \pm 144.7^{\mathrm{d}}$ & $92.3 \pm 142.5$ \\
\hline P1 north & $\mathrm{G}$ & 75 & $486.6 \pm 533.4^{\mathrm{bcd}}$ & $365.0 \pm 505.1$ \\
& $\mathrm{M}$ & 65 & $4.3 \pm 3.6^{\mathrm{abc}}$ & $2.8 \pm 3.2$ \\
\hline P2 north & $\mathrm{G}$ & 40 & $11250.0 \pm 29540.3^{\mathrm{ab}}$ & $4500.0 \pm 18800.8$ \\
& $\mathrm{M}$ & 60 & $2.7 \pm 3.4^{\mathrm{abc}}$ & $1.6 \pm 2.9$ \\
\hline P3 north & $\mathrm{G}$ & 90 & $983.3 \pm 1001.3^{\mathrm{bcd}}$ & $885.0 \pm 994.3$ \\
& $\mathrm{M}$ & 35 & $2.5 \pm 4.1^{\mathrm{a}}$ & $0.9 \pm 2.6$ \\
\hline P1 valley & $\mathrm{G}$ & 70 & $1004.7 \pm 3033.8^{\mathrm{ab}}$ & $703.3 \pm 2553.5$ \\
& $\mathrm{M}$ & 40 & $2.2 \pm 3.1^{\mathrm{ab}}$ & $0.9 \pm 2.2$ \\
\hline P2 valley & $\mathrm{G}$ & 80 & $283.3 \pm 189.3^{\mathrm{bcd}}$ & $226.6 \pm 204.4$ \\
& $\mathrm{M}$ & 80 & $6.8 \pm 5.6^{\mathrm{abcd}}$ & $5.5 \pm 5.7$ \\
\hline P3 valley & $\mathrm{G}$ & 75 & $275.5 \pm 260.4^{\mathrm{abc}}$ & $206.6 \pm 254.8$ \\
& $\mathrm{M}$ & 45 & $6.4 \pm 8.8^{\mathrm{abc}}$ & $2.9 \pm 6.3$ \\
\hline P1 west & $\mathrm{G}$ & 100 & $4956.4 \pm 11594.9^{\mathrm{b}}$ & $4956.4 \pm 11594.9$ \\
& $\mathrm{M}$ & 55 & $4.6 \pm 5.9^{\mathrm{abc}}$ & $2.5 \pm 4.8$ \\
\hline P2 west & $\mathrm{G}$ & 100 & $4136.3 \pm 8661.8^{\mathrm{cd}}$ & $4136,3 \pm 8661.8$ \\
& $\mathrm{M}$ & 90 & $15.1 \pm 25.2^{\mathrm{cd}}$ & $13.6 \pm 24.3$ \\
\hline P3 west & $\mathrm{G}$ & 100 & $566.3 \pm 375.6^{\mathrm{bcd}}$ & $566.3 \pm 375.6$ \\
& $\mathrm{M}$ & 45 & $4.3 \pm 6.5^{\mathrm{abc}}$ & $1.9 \pm 4.7$ \\
\hline & & & &
\end{tabular}

Table 5. Parasitological indices of Ichthyophthirius multifiliis in gills of Nile tilapia. Different letters indicate a significant difference in the lines by the Kruskal-Wallis test $(P<0.05)$. P: fish farming, P\%: prevalence, MI: mean intensity and MA: mean abundance (mean \pm standard deviation).

\begin{tabular}{lccc}
\hline Fish farming & P $(\%)$ & MI & MA \\
\hline P1 south & 45 & $377.7 \pm 210.8^{\mathrm{ab}}$ & $170 \pm 236.4$ \\
P2 south & 50 & $330.0 \pm 231.1^{\mathrm{b}}$ & $165 \pm 232.3$ \\
P3 south & 30 & $116.6 \pm 40.8^{\mathrm{a}}$ & $35 \pm 58.7$ \\
\hline P1 north & 0 & $0^{\mathrm{b}}$ & 0 \\
P2 north & 5 & $100 \pm 0^{\mathrm{b}}$ & $5 \pm 22.3$ \\
P3 north & 0 & $0^{\mathrm{b}}$ & 0 \\
\hline P1 valley & 0 & $0^{\mathrm{b}}$ & 0 \\
P2 valley & 0 & $0^{\mathrm{b}}$ & 0 \\
P3 valley & 0 & $0^{\mathrm{b}}$ & 0 \\
\hline P1 west & 95 & $1564.5 \pm 988.9^{\mathrm{a}}$ & $1486.3 \pm 1024.1$ \\
P2 west & 95 & $571.6 \pm 554.4^{\mathrm{a}}$ & $543.0 \pm 554.5$ \\
P3 west & 100 & $2419.6 \pm 1515.1^{\mathrm{a}}$ & $2419.6 \pm 1515.1$ \\
\hline
\end{tabular}

eastern regions of Brazil as well as in stressful situations (Martins \& Romero, 1996; Tavares-Dias et al., 2001). The temperature is a factor that influences the duration of the cycle of this parasite. In colder climates it can last several months, thus explaining the fact that, in apparently unaffected populations, massive infestations may develop suddenly as a consequence of the increase in water temperature, which demonstrates the need for constant surveillance in fish during the summer months (Eiras, 1994). The indexes reported in 
Table 6. Parasitological indices of Monogenea in gills of Nile tilapia. Different letters indicate a significant difference in the lines by the Kruskal-Wallis test $(P<0.05)$. P: fish farming, P\%: prevalence, MI: mean intensity, MA: mean abundance (mean \pm standard deviation).

\begin{tabular}{lrcc}
\hline Fish farming & $\mathrm{P}(\%)$ & IM & AM \\
\hline P1 south & 0 & $0^{\mathrm{ab}}$ & 0 \\
P2 south & 0 & $0^{\mathrm{ab}}$ & 0 \\
P3 south & 0 & $0^{\mathrm{ab}}$ & 0 \\
\hline P1 north & 15 & $1 \pm 0^{\mathrm{ab}}$ & $0.1 \pm 0.3$ \\
P2 north & 25 & $2 \pm 1.7^{\mathrm{ab}}$ & $0.5 \pm 1.1$ \\
P3 north & 95 & $100.4 \pm 65.3^{\mathrm{e}}$ & $95.4 \pm 67.4$ \\
\hline P1 valley & 70 & $3.3 \pm 3.5^{\mathrm{bcd}}$ & $2.3 \pm 3.3$ \\
P2 valley & 60 & $5.2 \pm 6.7^{\mathrm{bcd}}$ & $3.1 \pm 5.8$ \\
P3 valley & 100 & $9.1 \pm 9.1^{\mathrm{de}}$ & $9.1 \pm 9.1$ \\
\hline P1 west & 15 & $1.3 \pm 1.1^{\mathrm{b}}$ & $0.2 \pm 0.7$ \\
P2 west & 40 & $3.2 \pm 4.8^{\mathrm{bc}}$ & $1.3 \pm 3.3$ \\
P3 west & 80 & $13.9 \pm 22.3^{\text {cde }}$ & $13.1 \pm 20.6$ \\
\hline
\end{tabular}

Table 7. Hematological characteristics (mean \pm standard deviation) of Nile tilapia cultivated in fish farms in the state of Santa Catarina. Different letters indicate a significant difference between the columns by the Kruskal-Wallis test $(P<0.05)$. RBC: red blood cells, WBC: white blood cells, P: fish farming.

\begin{tabular}{|c|c|c|c|c|c|c|}
\hline \multirow{2}{*}{ Parameters } & \multicolumn{3}{|c|}{ South } & \multicolumn{3}{|c|}{ North } \\
\hline & P1 & $\mathrm{P} 2$ & P3 & P1 & $\mathrm{P} 2$ & P3 \\
\hline Hematocrit (\%) & $34.3 \pm 4.9^{\mathrm{ab}}$ & $32.7 \pm 3.6^{\mathrm{abc}}$ & $27.2 \pm 3.3^{\mathrm{e}}$ & $34.1 \pm 3.1^{\mathrm{a}}$ & $35.2 \pm 4.2^{\mathrm{a}}$ & $32.3 \pm 3.3^{\mathrm{abcd}}$ \\
\hline $\mathrm{RBC}\left(\times 10^{6} \mu \mathrm{L}^{-1}\right)$ & $2.3 \pm 5.2^{\mathrm{ab}}$ & $2.3 \pm 2.6^{\mathrm{a}}$ & $2.4 \pm 3.91^{\mathrm{a}}$ & $2.0 \pm 5.6^{\mathrm{ab}}$ & $1.8 \pm 6.0^{\mathrm{bc}}$ & $1.4 \pm 2.8^{c}$ \\
\hline $\mathrm{WBC}\left(\times 10^{3} \mu \mathrm{L}^{-1}\right)$ & $63.8 \pm 2.5$ & $112.0 \pm 2.9$ & $88.6 \pm 2.9$ & $70.9 \pm 3.1$ & $53.0 \pm 2.3$ & $37.3 \pm 1.5$ \\
\hline Lymphocytes $\left(\times 10^{3} \mu \mathrm{L}^{-1}\right)$ & $99.4 \pm 2.4^{\mathrm{a}}$ & $103.0 \pm 2.4^{\mathrm{a}}$ & $108.0 \pm 1.6^{\mathrm{a}}$ & $98.5 \pm 2.8^{\mathrm{a}}$ & $88.4 \pm 3.1^{\mathrm{abc}}$ & $63.6 \pm 1.9^{\mathrm{c}}$ \\
\hline Neutrophils $\left(\times 10^{3} \mu \mathrm{L}^{-1}\right)$ & $4.4 \pm 3.0^{\mathrm{ab}}$ & $1.4 \pm 1.6^{\mathrm{bcd}}$ & $1.2 \pm 1.5^{\mathrm{cd}}$ & $1.6 \pm 2.5^{\mathrm{cd}}$ & $0.1 \pm 0.2^{\mathrm{d}}$ & $1.7 \pm 2.2^{\mathrm{bcd}}$ \\
\hline Monocytes $\left(\times 10^{3} \mu \mathrm{L}^{-1}\right)$ & $9.9 \pm 4.2^{\mathrm{a}}$ & $17.8 \pm 13.2^{\mathrm{a}}$ & $12.2 \pm 6.4^{\mathrm{ab}}$ & $1.2 \pm 1.2^{\mathrm{c}}$ & $2.5 \pm 4.5^{\mathrm{bc}}$ & $1.8 \pm 2.3^{\mathrm{bc}}$ \\
\hline Thrombocytes $\left(\times 10^{3} \mu \mathrm{L}^{-1}\right)$ & $4.3 \pm 3.9^{\mathrm{bc}}$ & $6.6 \pm 5.4^{\mathrm{abcd}}$ & $2.0 \pm 3.7^{\mathrm{d}}$ & $13.2 \pm 8.8^{\mathrm{ab}}$ & $9.6 \pm 8.1^{\mathrm{abcd}}$ & $2.4 \pm 4.1^{\mathrm{cd}}$ \\
\hline \multirow{2}{*}{ Parameters } & \multicolumn{3}{|c|}{ Itajaí Valley } & \multicolumn{3}{|c|}{ West } \\
\hline & P1 & $\mathrm{P} 2$ & P3 & P1 & $\mathrm{P} 2$ & P3 \\
\hline Hematocrit (\%) & $28.1 \pm 4.3^{\text {cde }}$ & $30.3 \pm 3.4^{\text {abcde }}$ & $25.1 \pm 7.1^{\mathrm{de}}$ & $36.5 \pm 2.5^{\mathrm{ab}}$ & $32.7 \pm 2.9^{\mathrm{abc}}$ & $29.1 \pm 3.9^{\text {bcde }}$ \\
\hline $\mathrm{RBC}\left(\times 10^{6} \mu \mathrm{L}^{-1}\right)$ & $2.2 \pm 4.9^{\mathrm{ab}}$ & $2.0 \pm 3.6^{\mathrm{ab}}$ & $1.9 \pm 4.5^{\mathrm{abc}}$ & $2.3 \pm 5.1^{\mathrm{ab}}$ & $2.1 \pm 3.5^{\mathrm{ab}}$ & $2.1 \pm 3.1^{\mathrm{ab}}$ \\
\hline $\mathrm{WBC}\left(\times 10^{3} \mu \mathrm{L}^{-1}\right)$ & $104.0 \pm 3.0$ & $78.6 \pm 3.4$ & $47.4 \pm 2.2$ & $69.9 \pm 1.9$ & $60.4 \pm 1.8$ & $83.0 \pm 1.9$ \\
\hline Lymphocytes $\left(\times 10^{3} \mu \mathrm{L}^{-1}\right)$ & $99.8 \pm 2.6^{\mathrm{a}}$ & $94.1 \pm 1.9^{\mathrm{a}}$ & $83.8 \pm 2.0^{\mathrm{abc}}$ & $104.0 \pm 2.4^{\mathrm{a}}$ & $87.6 \pm 1.7^{\mathrm{abc}}$ & $85.4 \pm 1.1^{\mathrm{abc}}$ \\
\hline Neutrophils $\left(\times 10^{3} \mu \mathrm{L}^{-1}\right)$ & $1.3 \pm 1.7^{\mathrm{cd}}$ & $3.0 \pm 3.3^{\mathrm{abc}}$ & $6.9 \pm 4.8^{\mathrm{a}}$ & $6.3 \pm 6.1^{\mathrm{abc}}$ & $3.6 \pm 3.5^{\mathrm{abc}}$ & $4.1 \pm 3.6^{\mathrm{abc}}$ \\
\hline Monocytes $\left(\times 10^{3} \mu \mathrm{L}^{-1}\right)$ & $15.7 \pm 8.1^{\mathrm{a}}$ & $10.4 \pm 6.5^{\mathrm{a}}$ & $7.8 \pm 4.5^{\mathrm{ab}}$ & $2.8 \pm 3.4^{\mathrm{bc}}$ & $12.3 \pm 5.4^{\mathrm{a}}$ & $14.9 \pm 6.1^{\mathrm{a}}$ \\
\hline Thrombocytes $\left(\times 10^{3} \mu \mathrm{L}^{-1}\right)$ & $13.8 \pm 10.2^{\mathrm{ab}}$ & $11.6 \pm 11.4^{\mathrm{abc}}$ & $13.2 \pm 8.6^{\mathrm{ab}}$ & $22.7 \pm 9.9^{\mathrm{a}}$ & $8.9 \pm 6.6^{\mathrm{abcd}}$ & $12.5 \pm 9.7^{\mathrm{ab}}$ \\
\hline
\end{tabular}

this study are higher than observed by Zago et al. (2014) that reported the maximum prevalence of $38 \%$ and meant intensity of 100 parasites per fish in Nile tilapia parasitized by I. multifiliis. According to Lemos et al. (2007), this shows that, in Brazil, the same host may present a different pattern of this infestation, depending on the region in which it is being cultivated.

Monogenea helminths had higher average infestation intensity in fish culture 3 in the north region, which was characterized by a storage tank, in which several species of fish were allocated, that stocking density was unknown. The fact of not controlling the amount of fish in a nursery contributes to the dissemination of this parasite, which has a direct life cycle and has its proliferation and dissemination facilitated in high storage densities and poor water quality (Moraes \& Martins, 2004). The above mentioned may justify the results of the present study, mainly associated with poor sanitary management and mechanisms of parasite permanence in fish (Buchmann \& Lindenstrom, 2002).

In a study with Mugil platanus from an estuarinelagoon region in the state of São Paulo (Brazil), Ranzani-Paiva \& Silva-Souza (2004) observed that parasitism of the gills by Monogenea affects the weight 
of fish, especially when co-infected with Trichodina sp. and copepods, demonstrating the negative correlation of parasitism with the condition factor $(\mathrm{Kn})$. Contrary to what was observed in this study, in which Kn showed an only negative correlation $(\rho=-15)$ with Trichodina sp. in mucus and when associated with all parasites, there was no correlation. However, all fish farms analyzed in this study showed a Kn equal to or very close to 1, which indicates indirectly that the observed parasitism did not affect the growth and well-being of the fish, a fact that was also reported by Ranzani-Paiva et al. (2000) and Tavares-Dias et al. (2002).

In the present study, the number of monocytes exceeded the number of neutrophils, contrary to that observed in other studies (Hrubec et al., 2000; TavaresDias \& Moraes, 2003; Ghiraldelli et al., 2006b). However, the same situation was reported by Azevedo et al. (2006) in O. niloticus in fish-pay. On the other hand, the higher lymphocyte rates in relation to monocytes and neutrophils suggest that the fish were not submitted to stressors before blood withdrawal, since several studies have indicated lymphopenia and neutrophilia in fish under stress (Martins et al., 2002, 2004, 2006).

In $O$. niloticus highly infested by $I$. multifiliis and Saprolegnia sp, the neutrophil and monocyte percentages were significantly higher in the parasitized group, but the number of thrombocytes was equivalent between the two groups (Tavares-Dias et al., 2002). On the other hand, Tavares-Dias et al. (1999) reported the occurrence of thrombocytopenia and monocytosis in $P$. mesopotamicus parasitized with Argulus sp., corroborating the results of the present study, in which the same changes in the hematological profile of Nile tilapias parasitized with Trichodina sp., Monogenea and $I$. multifiliis were observed.

The values of thrombocytes in the present study were lower than those reported in several studies with tilapias (Hrubec et al., 2000; Tavares-Dias et al., 2002; Tavares-Dias \& Moraes, 2003; Azevedo et al., 2006; Ghiraldelli et al., 2006a). Thrombocytes are responsible for blood coagulation and play an essential role in phagocytosis, especially of cellular debris (Ranzani-Paiva et al., 2013). According to Nagasawa et al. (2015), in their study with carp, thrombocytes require activation factors secreted by other activated leukocytes to perform phagocytosis. Possibly thrombocytes have been activated and recruited from their reserve compartments to contribute to the mechanisms of organic defense (Tavares-Dias et al., 1999), justifying the thrombocytopenia observed in the present study. On the other hand, monocytes, which are the principal fish phagocytes (Tavares-Dias \& Moraes, 2004), in cases of infectious processes, migrate from the blood vessels to the inflammatory focus (Martins et al., 2009 and Santos et al., 2009), increased production in the bloodstream in order to supply the requirements for organic defenses, unlike thrombocytes that possibly were only sequestered for the focus of inflammation.

The correlations observed in the present study suggest that neutrophils and monocytes are involved in the organic defense of fish against the parasites found. Studies with $P$. mesopotamicus related the increase in the number of circulating monocytes against parasite infection (Tavares-Dias et al., 1999, 2008). However, monocytosis observed in this study refers in particular to I. multifiliis parasitism, given the positive correlation observed between the two.

Tavares-Dias et al. (1999), when studying the hematology and relative condition factor $(\mathrm{Kn})$ of parasitized $L$. macrocephalus and P. mesopotamicus, observed that despite the high level of Monogenea infestation, Trichodina sp., Lernaea cyprinacea Linnaeus, 1758 (Crustacea: Copepoda), P. pillulare and I. multifiliis, there were no changes in the studied parameters, possibly having a balance between parasites and hosts. In contrast to the report mentioned above, in the present study, the high infestations did not influence the relative condition factor, but the alterations observed in the blood count suggest a direct relationship with the parasitic infestation.

Even without apparent losses in production, such as inadequate growth and/or mortality, the parasites of this study had a direct influence on fish health, as could be observed through changes in the blood count. The hematological profile of the tilapias showed the sequestration and use of cellular components of organic defense, possibly as a function of parasitism. Thus, parasites can divert the immune response of the fish, compromising them against any future adverse events.

\section{CONCLUSIONS}

The tilapia organic defense system was effective against the observed parasitism, so as not to affect the physiological state of animals and growth. Thus, the monocytosis and thrombocytopenia conditions were possibly due to the high parasitic intensities caused by Trichodina spp., I. multifiliis, and Monogenea. The correlations observed in the present study suggest that neutrophils and monocytes are directly involved in the organic defense of fish against parasites, and monocytes are primarily related to I. multifiliis infection.

\section{ACKNOWLEDGMENTS}

The authors are grateful to Luiz Rodrigo Motta Vicenti (Epagri), Ofélia Maria Campigotto (Gaspar fish farmers' association), Susane Pahl-Klipp (Municipal 
Rural Development Foundation July 25) and Marcelo Tonial and Alexander Hilata (Nicolluzi) for assistance in collecting and to the fish farms of the state of Santa Catarina that donated the fish. The authors thank Dr. Evoy Zaniboni Filho, Dra. Natália Costa Marchiori and Dr. Eduardo Cargnin for critical review of the manuscript prior to submission. We thank National Council for Scientific and Technological Development (CNPq) for their financial support (CNPq 446072/ 2014-1) and grant to M.L. Martins (CNPq 305869/ 2014-0), the Improvement Coordination Higher Level Personnel (CAPES-EMBRAPA n. 15/2014) for award of the Master's scholarship to L.D. Steckert , PostDoctoral scholarship to G.T. Jerônimo (CNPq 402434/ 2016-1) and CAPES Finance code 001.

\section{REFERENCES}

Azevedo, T.M.P., Martins, M.L., Yamashita, M.M. \& Francisco, C.J. 2006. Hematologia de Oreochromis niloticus: comparação entre peixes mantidos em piscicultura consorciada com suínos e em pesquepague no Vale do Rio Tijucas, Santa Catarina, Brasil. Boletim do Instituto de Pesca, 32: 41-49.

Blaxhall, P.C. \& Daisley, K.W. 1973. Routine hematological methods for use with fish blood. Journal of Fish Biology, 5: 71-81.

Buchmann, K. \& Lindenstrom, T. 2002. Interactions between monogenean parasites and their fish hosts. International Journal for Parasitology, 32: 309-319.

Bush, A.O., Lafferty, K.D. \& Lotz, J.M. 1997. Parasitology meets ecology on its own terms. Margolis et al. revisited. Journal of Parasitology, 83: 575-583.

Eiras, J.C. 1994. Elementos de ictioparasitología. Fundação Eng. Antonio de Almeida, Porto.

Food and Agriculture Organization of the United Nations (FAO). 2006. The state of world fisheries and aquaculture. Contributing to food security and nutrition for all. FAO, Rome.

Fitzsimmons, K., Martínez-Garcia, R. \& Gonzáles-Alanis, P. 2011. Why tilapia is becoming the most important food fish on the planet. In: Liping, L. \& Fitzsimmons, K. (Eds.). Better science, better fish, better life: proceedings of the ninth International symposium on tilapia in aquaculture. Aquafish CRPS, Shanghai, pp. 9-18.

Ghiraldelli, L., Martins, M.L., Jerônimo, G.T., Yamashita, M.M. \& Adamante, W.B. 2006a. Ectoparasites communities from Oreochromis niloticus cultivated in the State of Santa Catarina, Brazil. Journal of Fisheries and Aquatic Science, 1: 181-190.

Ghiraldelli, L., Martins, M.L., Yamashita, M.M. \& Jerônimo, G.T. 2006b. Ectoparasites influence on the hematological parameters of Nile tilapia and carp cultured in the State of Santa Catarina, South Brazil. Journal of Fisheries and Aquatic Science, 1: 270-276.

Ghiraldelli, L., Martins M.L., Adamante W.B. \& Yamashita M.M. 2006c. First record of Trichodina compacta Van As and Basson, 1989 (Protozoa: Ciliophora) from cultured Nile tilapia in the state of Santa Catarina, Brazil. International Journal of Zoological Research, 2: 369-375.

Guidelli, G., Takemoto, R.M. \& Pavanelli, G.C. 2009. Ecologia das infrapopulações ectoparasitas das cavidades nasais de Leporinus lacustris (Anostomidae) da planície de inundação do alto rio Paraná, Brasil. Acta Scientiarum, Biological Sciences, 31: 209-214.

Hrubec, T.C., Cardinale, J.L. \& Smith, S.A. 2000. Hematology and plasma chemistry reference intervals for cultured tilapia (Oreochromis hybrid). Veterinary Clinical Pathology, 29: 7-12.

Ishikawa, N.M., Ranzani-Paiva, M.J.T. \& Lombardi, J.V. 2008. Total leukocyte counts methods in fish, Oreochromis niloticus. Archives of Veterinary Science, 13: 54-63.

Jerônimo, G.T., Speck, G.M., Cechinel, M.M., Gonçalves, E.L.T. \& Martins, M.L. 2011. Seasonal variation on the ectoparasitic communities of Nile Tilapia cultured in three regions in Southern Brazil. Brazilian Journal of Biology, 71: 365-373.

Khaw, H.L., Ponzoni, R.W., Hamzah, A., Abu-Bakar, K.R. \& Bijma, P. 2012. Genotype by production environment interaction in the GIFT strain of Nile tilapia (Oreochromis niloticus). Aquaculture, 326: 5360.

Kubitza, F. 2000. Tilápia: tecnologia e planejamento na produção comercial. Editora Kubitza, Jundiaí.

Le Cren, E.D. 1951. The length-weight relationship and seasonal cycle in gonad weight and condition factor in the perch (Perca fluviatilis). Journal of Animal Ecology, 20: 201-219.

Lemos, J.R.G., Tavares-Dias, M., Sales, R.S.A., NobreFilho, G.R. \& Fim, J.D.I. 2007. Parasitos nas brânquias de Brycon amazonicus (Characidae, Bryconinae) cultivados em canais de igarapé do Turumã-Mirim, Estado do Amazonas, Brasil. Acta Scientiarum, Biological Sciences, 29: 217-222.

Martins, M.L. \& Ghiraldelli, L. 2008. Trichodina magna Van As and Basson, 1989 (Ciliophora: Peritrichia) from cultured Nile tilapia in the state of Santa Catarina, Brazil. Brazilian Journal of Biology, 68: 169-172.

Martins, M.L. \& Romero, N.G. 1996. Efectos del parasitismo sobre el tejido branquial en peces cultivados: estudio parasitologico e histopatologico. Revista Brasileira de Zoologia, 13: 489-500. 
Martins, M.L., Cardoso, L., Marchiori, N.C. \& Pádua, S.B. 2015. Protozoan infections in farmed fish from Brazil: diagnosis and pathogenesis. Revista Brasileira de Parasitologia Veterinária, 24: 1-20.

Martins, M.L., Xu, D.H., Shoemaker, C.A. \& Klesius, P.H. 2011. Temperature effects on immune response and hematological parameters of channel catfish Ictalurus punctatus vaccinated with live theronts of Ichthyophthirius multifiliis. Fish and Shellfish Immunology, 31: 774-780.

Martins, M.L., Moraes, F.R., Fujimoto, R.Y., Nomura, D.T. \& Fenerick Jr., J. 2002. Respostas do híbrido tambacu (Piaractus mesopotamicus Holmberg, 1887 macho X Colossoma macropomum Cuvier, 1818 fêmea) a estímulos simples ou consecutivos de captura. Boletim do Instituto de Pesca, 28: 195-204.

Martins, M.L., Moraes, F.R., Fujimoto, R.Y., Onaka, E.M., Bozzo, F.R. \& Moraes, J.R.E. 2006. Carrageenin induced inflammation in Piaractus mesopotamicus (Osteichthyes: Characidae) cultured in Brazil. Boletim do Instituto de Pesca, 32: 31-39.

Martins, M.L., Miyazaki, D.M.Y., Tavares-Dias, M., Fenerick Jr., J., Onaka, E.M., Bozo, F., Fujimoto, R.Y. $\&$ Moraes, F.R. 2009. Characterization of the acute inflammatory response in the hybrid tambacu (Piaractus mesopotamicus male x Colossoma macropomum female) (Osteichthyes). Brazilian Journal of Biology, 69: 631-637.

Martins, M.L., Pilarski, F., Onaka, E.M., Nomura, D.T., Fenerick Jr., J., Ribeiro, K., Myiazaki, D.M.Y., Castro, M.P. \& Malheiros, E.B. 2004. Hematologia e resposta inflamatória aguda em Oreochromis niloticus (Osteichthyes: Cichlidae) submetida aos estímulos único e consecutivo de estresse de captura. Boletim do Instituto de Pesca, 30: 71-80.

Moraes, F.R. \& Martins, M.L. 2004. Condições predisponentes e principais enfermidades de teleósteos em piscicultura intensiva. In: Cyrino, J.E.P., Urbinati, E.C., Fracalossi, D.M. \& Castagnolli, N. (Eds.). Tópicos especiais em piscicultura de água doce tropical intensiva. Editora TecArt, São Paulo, pp. 343386.

Ministério da Pesca e da Aquicultura (MPA). 2015. Plano Safra - Pesca e Aquicultura. Brasília, pp. 12-117.

Nagasawa, T., Sonamoto, T. \& Naka, M. 2015. Carp thrombocyte phagocytosis requires activation factors secreted by other leukocytes. Developmental and Comparative Immunology, 52: 107-111.

Nunes, G.C., Jerônimo, G.T., Vicente, L.R.M., Madi, R.R., Valladão, G.R.M. \& Martins, M.L. 2016. Trace elements and parasitism in Nile tilapia farmed in southern Brazil. Boletim do Instituto de Pesca, 42: 578-589.

Paperna, I. \& Thurston, J.P. 1969. Monogenetic trematodes collected from cichlid fish in Uganda; including the description of five new species of Cichlidogyrus. Revue de Zoologie et de Botanique Africaines, 79: 1-2.

Pariselle, A. \& Euzet, L. 1995. Gill parasites of the genus Cichlidogyrus Paperna, 1960 (Monogenea, Ancyrocephalidae) from Tilapia guineensis (Bleeker, 1862), with descriptions of six new species. Systematic Parasitology, 30: 187-198.

Pilloux, L., Aeby, S., Gaumann, R., Burri, C., Beuret, C. \& Greub, G. 2015. The high prevalence and diversity of Chlamydiales DNA within Ixodes ricinus ticks suggest a role for ticks as reservoirs and vectors of Chlamydia-related bacteria. Applied and Environmental Microbiology, 81: 8177-8182.

Ranzani-Paiva, M.J.T. \& Silva-Souza, A.T. 2004. CoInfestation of gills by different parasite groups in the mullet, Mugil platanus Gunther, 1880 (Osteichthyes, Mugilidae): effects on relative condition factor. Brazilian Journal of Biology, 64: 677-682.

Ranzani-Paiva, M.J.T., Felizardo, N.N. \& Luque, J.L. 2005. Parasitological and hematological analysis of Nile tilapia Oreochromis niloticus Linnaeus, 1757 from Guarapiranga Reservoir, São Paulo State, Brazil. Acta Scientiarum, Biological Sciences, 27: 231-237.

Ranzani-Paiva, M.J.T., Pádua, S.B., Tavares-Dias, M. \& Egami, M.I. 2013. Métodos para análise hematológica em peixes. Eduem, Maringá.

Ranzani-Paiva, M.J.T., Silva-Souza, A.T., Pavanelli, G.C. \& Takemoto, R.M. 2000. Hematological characteristics and relative condition factor $(\mathrm{Kn})$ associated with parasitism in Schizodon borelli (Osteichthyes, Anostomidae) and Prochilodus lineatus (Ostrichthyes, Prochilodontidaes) from Paraná River, Paraná, Brazil. Acta Scientiarum, Biological Sciences, 22: 515-521.

Santos, A.A., Egami, M.I., Ranzani-Paiva, M.J.T. \& Juliano, Y. 2009. Hematological parameters and phagocytic activity in fat snook (Centropomus parallelus): season variation, sex and gonadal maturation. Aquaculture, 296: 359-366.

Singhal, R.N., Jeet, S. \& Davies, R.W. 1990. The effects of argulosis-saprolehniasis on the growth and production of Cyprinus carpio. Hydrobiologia, 2: 2731 .

Takemoto, R.M., Luque, J.L., Bellay, S., Longhini, C.E. \& Graça, R.J. 2013. Monogenea. In: Pavanelli, G.C., Takemoto, R.M. \& Eiras, J.C. (Eds.). Parasitologia de peixes de água doce do Brasil. Eduem, Maringá, pp. 273-299.

Tavares-Dias, M. \& Moraes, F.R. 2003. Características hematológicas da Tilapia rendalli Boulenger, 1896 (Osteichthyes: Cichlidae) capturada em pesque-pague de Franca, São Paulo, Brasil. Bioscience Journal, 1: 107-114. 
Tavares-Dias, M., Marchiori, N.C. \& Martins, M.L. 2013. Paratrichodina africana (Ciliophora: Trichodinidae) of wild and cultured Nile tilapia in the northern Brazil. Revista Brasileira de Parasitologia Veterinária, 22: 248-252.

Tavares-Dias, M., Martins, M.L. \& Kronka, S.N. 1999. Evaluation of the hematological parameters in Piaractus mesopotamicus Holmberg (Osteichthyes, Characidae) with Argulus sp. (Crustacea, Branchiura) infestation and treatment with organophosphate. Revista Brasileira de Zoologia, 16: 553-555.

Tavares-Dias, M., Moraes, F.R. \& Martins, M.L. 2008. Hematological assessment in four Brazilian teleost fish with parasitic infections, collected in fee fishing from Franca, São Paulo, Brazil. Boletim do Instituto de Pesca, 34: 189-196.

Tavares-Dias, M., Martins, M.L., Moraes, F.R. \& Kronka, S.N. 2000. Fator de condição e relação hepato e esplenossomática em teleósteos de água doce naturalmente parasitados. Acta Scientiarum, Biological Sciences, 22: 533-537.

Tavares-Dias, M., Moraes, F.R., Martins, M.L. \& Kronka, S.N. 2001. Fauna parasitária de peixes oriundos de "pesque-pagues" do município de Franca, São Paulo, Brasil. I. Protozoários. Revista Brasileira de Zoologia, 18: 67-79.

Tavares-Dias, M., Moraes, F.R., Martins, M.L. \& Santana, A.E. 2002. Hematological changes in Oreochromis niloticus (Osteichthyes: Cichlidae) with gill ichthyophthiriasis and saprolegniasis. Boletim do Instituto de Pesca, 28: 1-9.

Tavares-Dias, M., Ishikawa, M.M., Martins, M.L., Satake, F., Hisano H., Pádua, S.B., Jerônimo, G.T. \& Sant Ana, A.R. 2009. Hematologia: ferramenta para o monitoramento do estado de saúde de peixes em cultivo. In: Saran-Neto, A., Mariano, W.S. \& Sória, S.F. (Eds.). Tópicos especiais em saúde e criação animal. Editora Pedro \& João, Dourados, pp 43-80.

Received: 27 September 2018; Accepted: 22 March 2019
Valladão, G.M.R., Gallani, S.U., Pádua, S.B., Martins, M.L. \& Pilarski, F. 2014. Trichodina heterodentata (Ciliophora) infestation on Prochilodus lineatus larvae: a host-parasite relationship study. Parasitology, 141: 662-669.

Vicente, I.S.T., Elias, F. \& Fonseca-Alves, C.E. 2014. Perspectivas da produção de tilápia do Nilo (Oreochromis niloticus) no Brasil. Revista de Ciencias Agrícolas, 37: 392-398.

Xu, D.H., Shoemaker, C.A. \& Klesius, P.H. 2012. Ichthyophthirius multifiliis as a potential vector of Edwardsiella ictaluri in channel catfish. FEMS Microbiology Letters, 329: 160-167.

Yamada, F.H., Takemoto, R.M. \& Pavanelli, G.C. 2008. Relação entre fator de condição relativo $(\mathrm{Kn}) \mathrm{e}$ abundância de ectoparasitos de brânquias, em duas espécies de ciclídeos da bacia do rio Paraná, Brasil. Acta Scientiarum, Biological Sciences, 30: 213-217.

Zago, A.C., Franceschini, L., Garcia, F., Schalch, S.H.C., Gozi, K.S. \& Silva, R.J. 2014. Ectoparasitas de tilápias-do-Nilo (Oreochromis niloticus) criadas em tanques-rede em um reservatório de usina hidrelétrica no Brasil. Revista Brasileira de Parasitologia Veterinária, 23: 171-178.

Zaniboni-Filho, E. 2004. Piscicultura das espécies nativas de água doce. In: Poli, C.R., Poli, A.T.B., Andreatta, E. \& Beltrame, E. (Eds.). Aqüicultura. Experiências brasileiras. Multitarefa Editora, Florianópolis, pp. 337368.

Zanolo, R. \& Yamamura, M.H. 2006. Parasites in tilapia of nile in fresh water net-tank system. Semina: Ciências Agrárias, 27: 281-288. 